Editorial

\title{
On Incorporating the University
}

Higher Education Policy (2006) 19, 129-134. doi:10.1057/palgrave.hep.8300123

One of the more fascinating aspects of the torrent of reform, overhauling and re-engineering that systems of higher education face today, lies in precisely what it is all leading to. There is, to be sure, wide agreement principally about the means - efficiency, quality, enterprise and competition, applied across the board from student entry, 'through-put' and graduation, to academic productivity, revenue raising and improvements to the managerial instrumentality which current wisdom sees as the best way to bring this about. Despite the metaphysical construction of such concepts as 'the Knowledge Society', 'the Network Society' 'the Learning Society' or for that matter the erection to similar status of general processes - pace 'Globalization' and its various regional subsets, which all clamour for various forms of 'integration', 'mobility' or 'new architectures' - the ends, however, remain operationally opaque in the extreme.

\section{Operationalizing Utopia}

Operationalizing Utopia is never an easy task. For if we are aware of those shortcomings and the once notorious inefficiencies in higher education that new public management set out to eradicate, we are rather less clear about how we are to move from what is to what ought to be. Thus, a very good case could be made for seeing that contemporary shibboleth of institutional flexibility less as a virtue than as the despair of working towards any long-term purposive 'vision'. Certainly, ability to adapt is the very condition of survival - in the short term. Whether what is rapidly adopted is sustainable in the long term is an entirely different matter. To which the cunning and perspicacious will reply that flexibility is effectively its own virtue, if only for the fact that by having it, our institutions should at least in theory, also possess that self-same capacity to get themselves out of a hole once they recognize they have fallen into it! Whether Ministries have the same versatility is a question best not asked.

Such visions of higher education as the portal to the Knowledge Society, to Regional Integration or to the 'Network Society', contending and often complementary though they are to one another, are interesting both in their underlying presumptions and in the place those presumptions have in the choppy waters of higher education policy. The presumptions are two: first, 
there is the presumption that current higher education development drives ineluctably towards the realization of 'Globalizing the planet' 'Networking the World'. Second, there is the correlative that accompanies such generics namely the way research acts as the handmaiden for verifying this self same determinism. Developments in Higher education are almost exclusively described in terms of how far higher education has moved along the Yellow Brick Road that leads on to and ends up in outcomes hypothetical at the very least or projected at best. There is, in effect, little attempt to ascertain whether the current condition of higher education - regardless of whether analyses focus on the system or on the institutional level — is capable of being presented in terms other than the apparently unavoidable and indisputable progress along the high road toward the various Holy Graals that riddle the imagination of politicians, international functionaries and those having weight and substance in the world of higher education policy.

To be sure, we can agree or disagree on the consequences. We can rattle our swords and sharpen our quills about whether the globalization of higher education does weaken the role of national administration, whether the Nation State will wither on the vine, or whether the dizzy circulation of goods, capital and people will contribute astoundingly to the forging of friendship between Nations whose history has largely been given over to the comforting reassurance of mutual disapproval and withering scorn. One may take the view that such developments are desirable or detestable just as one can argue about the consequences marketization, commodification and privatization in school and university may possibly have for national identity, professional identity, social cohesion or, for that matter, the place of social solidarity within individual cultures and countries. Nevertheless, we take as given that higher education is moving along this path even though the route taken is largely a construction that follows on from accepting the original hypothesis or vision. In such a circular reasoning, evaluation of institutional and systems progress appears to have no small kinship with the exercise of assessing how far the selffulfilling prophecy has proceeded down the road to its own self-fulfillment!

\section{Two Perspectives on 'Going Corporate'}

As in any reform, one question that inevitably emerges - sometimes sooner, at others later - is 'How far have we come? How much farther have we to go?' In his wide-ranging examination of the 'radical transformation' the university has been through over the past decade, Harpur poses it four square: 'How far down the corporate policy track must the university go?'

The question is both straightforward and subtle for there are, at the very least, two different perspectives to the notion of 'incorporation' that is, the 
injection into the university of corporative, firm-based techniques for administration, measurement of performance at various levels of aggregation and disaggregation, and for the setting of institutional priorities. Harpur's analysis looks at the contemporary background to the ways in which the university 'goes corporate'. Linguistically, this phrase itself carries very particular implications - in this case, that the decision to assimilate such firm-derived procedures and techniques is wholly the result of decisions consciously and knowingly taken by the individual establishment. There is an alternative view, however. It tends to be a little more dubious about whether the decision to take on 'corporate values' can be construed simply as an affair of university leadership.

This second perspective emerges in the notion of 'incorporation'. Both terms 'going corporate' and 'incorporation' involve the same basis process namely, the penetration into the world of teaching, learning and research of norms, practices and procedures that derive from business, technology or engineering - in short from the 'corporate' sector. Whereas 'going corporate' places the initiative firmly in the ambit of the individual university, the concept of 'incorporation' is the reverse of the very same medal. It places the individual university as the object of 'incorporation'. Thus, the initiative for creating the conditions of 'incorporation' lies well beyond the groves of academe. Interestingly, the process of 'incorporation, which involves bringing to bear upon an organization - in this case, higher education - the norms, practices and procedures that the 'incorporating body' holds indispensable for its survival at least or well-being at best - is not a wholly contemporary development. There is an earlier edition of 'incorporation'. Though rarely acknowledged in such terms, the earlier version may serve as a species of datum against which its present day counterpart may be placed. Effectively, it provides an historic backdrop to the line of argument Harpur pursues.

\section{'Incorporation': A Theme in University/Government Relations}

'Incorporating' higher education into the productive sector, which Harpur identifies inter alia with the penetration of 'business process modelling' into higher education, when seen from an historic perspective - and depending on one's chronology - stands at the very least as the second if not the third wave in the ebb and flow of 'incorporation'. Much of the 19th century in Europe was taken up with an earlier form of 'incorporation' which turned around the transfer of ownership, funding and oversight of individual universities to the Nation, together with the change in status of the academic estate to that of officially appointed public servants (Huisman et al., 2001; for Sweden see Jonasson, 2006; for Germany Hennnigsen, 2006). The earlier form of 
'incorporation' came as an answer to many issues, most of which remain current even today, though the answers its present day edition provides very often take higher education along a radically different pathway. Stated simply, the key issues then were the modernization of society; the introduction of merit as the basis for public responsibility; the creation of a State resting upon Law rather than on Might; the setting of national standards; and the validation of those particular forms of knowledge that forged national identity, contributed to the efficiency of government and administration and which set national benchmarks for individual achievement.

These were issues both central and strategic. They remain so today, and their importance is recognized through the establishment of specialist agencies each with a specific remit to deal with what many universities either dealt with on their own or formed part of a general oversight once exercised by national Administration - Agencies for Quality Assurance, Committees of Evaluation and Councils for Accreditation. The first 'incorporation' had the national civil service as its 'referential institution'. State service provided the basic norms and criteria for academic employment and indeed many of its ranks and their emoluments as late as the 1980 s, were closely aligned on corresponding posts in the civil service (CRE, 1986, 1987).

The second 'incorporation', which can be seen as the Leitmotif in higher education policy from around 1990 in Europe (earlier in the Anglo Saxon systems of Australia, Britain and the United States) by contrast, has as its referential institution, not public service but the large international firm.

Seen in this light, Harpur's dissection of the second incorporation sets the scene for those articles that follow. Each focuses on different dimensions affected by the second 'incorporation'. Grant Harman examines the way academia in Australia has come to grips with industry-based research funding and the impact that change has had upon academic output. Walters, however, attends to another constituency, namely the Student Estate and in a slightly different setting. He examines the gender dimension in the transition from higher education to the labour market, and more particularly how graduation from different types of establishment in Canada influences the chances of employment.

\section{Transforming Privilege, Incorporating Penalty}

As recent events have shown in France, as 'radical change' works its way through society and massification of higher education pushes up against what Trow termed the 'universal level' of attendance (Trow, 1974), being a graduate no longer guarantees a job, though it does significantly diminish the chances of being unemployed and very certainly so compared to those who have not 
studied beyond secondary school. For the majority of students, the prospect of higher education removes the historic privilege that once surrounded it. This is not to say that benefits are not still to be had. For in effect, studying beyond school seems to lessen the degree of penalty that a society driven by market forces imposes on its disadvantaged members and early leavers most especially so. Whether this change in the returns from higher education is perceived as a continued and unjustifiable privilege by premature school leavers is most assuredly an issue that deserves closer attention by the students of higher education policy and particularly those concerned with the social consequences of spiraling access rates.

Institutional stratification and differentiation are salient features of mass higher education driven by competition. This issue is developed by Aylon and Yogev from the Israeli setting and by Ahola from the Finnish context. The two articles are largely complementary. While the former concentrates on the type of students, their educational background and achievement levels who take up places in the non-university sector, the latter examines the issue from the standpoint of national policy and its consequences for institutional identity, mission and purpose.

Knight and Freeman's contribution touches upon an especially delicate issue namely, cross-national staff recruitment practices of business schools. Business schools are of more than passing interest. For many - and for themselves not least - Business Schools are symbolic as the cutting edge of the 'second incorporation', quite apart from serving as an important channel that injects business techniques back into university administration. Furthermore, Business Schools can claim to be the most ardent supporters of both the mobility of labour and the globalization of business. Il y va de leur métier. Yet, even here, as Knight and Freeman's article makes plain, the power of 'professional reproduction' is astoundingly persistent. Despite the rhetoric of 'global presence' and global mobility, it appears that local editions of 'the network society' are not always compatible with academic mobility on an intercontinental base. Beneath the new-style 'networking' certain loyalties and perceptions that tied together 'old boy' networks have not entirely vanished.

Finally, the article by Leisyte and Kizniene takes us into a central part of the process by which corporatization infiltrates higher education. This they do by examining the gradual penetration of the modes of discourse and the rationale for reform, which the theory of New Public Management currently occupies in Lithuanian higher education policy. Their analysis of developments over the past decade and a half shows up an interesting aspect of policy-making to wit, the use of a theory to provide a semblance of cohesion and coherence to measures initiated in their original form as pragmatic responses to issues both immediate and pressing. This is not a behaviour exclusive to Lithuania. Others have detected a similar comportment in Britain of the mid-1980s (Williams, 
2004). The authors also reveal some of the powerful influences at play behind the twin notions of competition and convergence, which underlie so many of the current visions that urge higher education onward - namely, the search to acquire legitimacy by justifying policy in terms that enjoy legitimacy - and apparent success - elsewhere; second, the conviction that such policy is appropriate precisely because it has been adopted elsewhere on the one hand and to avoid giving the impression of standing aside from a wisdom tried and tested, on the other. In policy, just as in personal relationships, emulation is often the sincerest form of flattery.

Guy Neave

\section{References}

CRE. (1986) 'European University Systems Part I', CRE Bulletin No. 75, Standing Conference of Presidents, Rectors and Vice-Chancellors of the European Universities; Third Quarter 1986; Geneva. Conférence des Recteurs Européens, 140pp.

CRE. (1987) 'European University Systems Part II', CRE Bulletin No. 77, First Quarter 1987; Geneva. Conférence des Recteurs Européens, 136pp.

Hennnigsen, B. (2006) 'A Joyful Good-Bye to Wilhelm von Humboldt: The German University and the Humboldtian Ideals of 'Einsamkeit and Freiheit', in G. Neave, K. Bluckert and T. Nybvom (eds.). The European Research University: An Historical Parenthesis?, New York: Palgrave Macmillan, pp. 91-108.

Huisman, J., Maassen, P. and Neave, G. (eds.). (2001) Higher Education and the Nation State, Oxford: Elsevier-Pergamon for IAU, 267pp.

Jonasson, I. (2006) 'Universities, Research and Politics', in G. Neave, K. Bluckert and T. Nybvom (eds.). The European Research University: An Historical Parenthesis?, New York: Palgrave Macmillan, pp. 51-60.

Trow, M. (1974) 'Problems in the Transition from Elite to Mass Higher Education', in Policies for Higher Education, from the General Report on the Conference on Future Structures of PostSecondary Education. Paris: OECD, pp. 55-101.

Williams, G. (2004) 'The Higher education market in the United Kingdom', in P. Teixeira, B. Jongbloed, D. Dill and A. Amaral (eds.). Markets in Higher Education: Rhetoric or Reality?, Dordrecht/Boston/London: Kluwer Academic Publishers. 